\title{
3 次元人体解剖学的モデルによる空胴共振器アプリケータの加温制御 Heating Control of Resonant Cavity Applicator for 3-D Anatomical Human Head Model
}

\author{
○学 井関 祐也（明治大） 学 中根 和也（明治大） 正 新藤 康弘（明治大） \\ 久保 允則 (オリンパス) 正 加藤 和夫（明治大）
}

Yuya Iseki, Nakane Kazuya, Shindo Yasuhiro, Mitsunori Kubo and Kazuo Kato

Meiji University, 1-1-1 Higashimita, Tama-ku, Kawasaki, Kanagawa 214-8571

\begin{abstract}
This paper describes a new heating control method of a resonant cavity applicator with a dielectric bolus for a 3-D anatomical human head model. We have already proposed the resonant cavity applicator for deep seated brain tumors hyperthermia treatments. In this paper, first, the method using dielectric bolus was described. Second, the 3-D anatomical human head model which was reconstructed from 2-D MRI and X-ray CT images was presented. Finally, from the result of temperature distributions with blood flow rate, it was found that the proposed method was useful for effective hyperthermia treatment.
\end{abstract}

Key Words: resonant cavity applicator, 3-D anatomical human model, brain tumor

1. はじめに

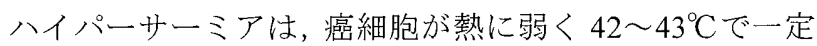
時間加温すると死滅するという臨床事実に基づいている.

本研究室では, 非接触・非侵襲での脳腫瘍のハイパーサ 一ミアが可能な空胴共振器加温方式を提案し, 実験的及び 数值的検討の両面から，本加温方式の有用性を示してきた (1).これまで著者らは, 被加温体である人体頭頂部に誘電 体を満たしたボーラスを設置する方法を提案し, 有効な加 温位置制御の可能性を示してきた ${ }^{(2)}$.

本報では，MRI や X 線 CT 等の 2 次元医用画像から作成 した 3 次元人体解剖学的モデルを用い, 血流による冷却効 果を考慮した温度分布解析により，本加温位置制御方法の 有用性を数值的に示した。

\section{2. 解析モデル}

図 1 は, 空胴共振器加温装置の概略を示している.なお, 空胴共振器の各寸法を図中に示した。 図 1 に示すように, 本加温方式では空胴共振器内部にリエントラントと呼ばれ る一対の内部電極を設けている，本加温方式は，共振周波 数に応じた種々の電磁界共振モードを空胴共振器内部に発 生させることで，間隙に設置した頭部を非接触状態で深 部・局所加温が可能である。図 1 に示すように，頭頂部に は純水などの誘電体を満たしたボーラスと呼ばれる水袋を 設置している.

図 2 は, 2 次元医用画像から再構築した, 3 次元人体解剖 学的モデルの詳細図である.本解析モデルは白質, 灰白質, 腫瘍, 頭蓋骨, 眼球, 心臓等の組織から構成されている. この解析モデルの総要素数は $1,631,388$ であった.

表 1 に, 電磁界周波数 $150 \mathrm{MHz}$ にお方, 生体組織の諸 パラメーターを示した (3),(4). なお，本検討では，誘電体ボ ーラスの物性值は純水のそれとした。

解析に用いた支配方程式を式(1)から式(5)に示した.なお, 本検討では式(5)の基礎代謝による項は, 他の項よりも十分 值が小さいため無視している. 式(2)の生体熱伝導方程式か らわかるように, 血流による冷却項 $\left(\mathrm{W}_{\mathrm{c}}\right)$ を考慮することは, ハイパーサーミアの温度分布解析において, 無視すること のできない重要な課題である，本検討では，組織の血流量 を定数とし，血流による冷却効果を考慮した計算アルゴリ ズムにより，温度分布解析を行った。図 3 は，血流を考慮 した計算アルゴリズムの流れ図を示している.

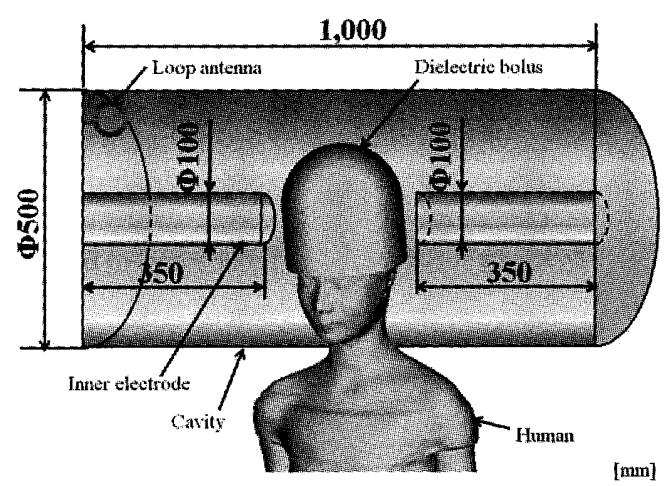

Fig. 1 Diagram of the cavity.

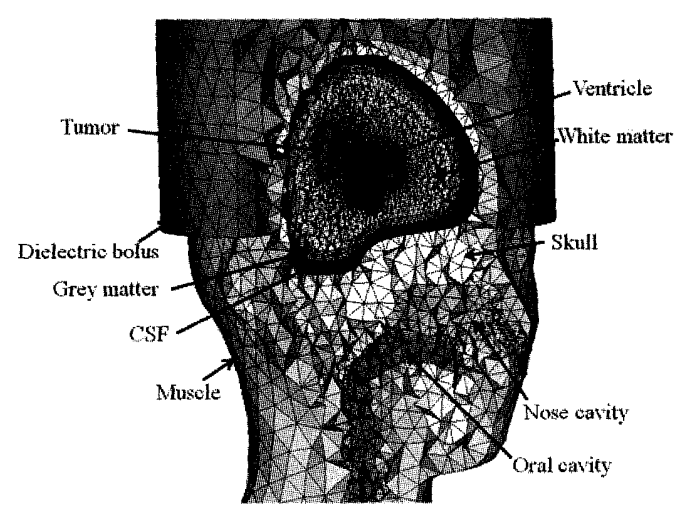

Fig. 2 Detail view of the 3-D FEM model.

Table1 Physical parameters at $150 \mathrm{MHz}$

\begin{tabular}{ccccccc}
\hline Tissue & $\sigma[\mathrm{S} / \mathrm{m}]$ & $\varepsilon_{\mathrm{r}}$ & $\mathrm{k}\left[\mathrm{W} / \mathrm{m} \cdot{ }^{\circ} \mathrm{C}\right]$ & $\mathrm{c}\left[\mathrm{J} / \mathrm{kg} \cdot{ }^{\circ} \mathrm{C}\right]$ & $\mathrm{\rho}\left[\mathrm{kg} / \mathrm{m}^{3}\right]$ & $\mathrm{B} \times 10^{-6}\left[\mathrm{~m}^{3} / \mathrm{kg} \cdot \mathrm{s}\right]$ \\
\hline Tumor & 0.72719 & 62.179 & 0.5 & 3,437 & 1.040 & 4.167 \\
Ventricle/CSF & 2.16060 & 81.169 & 0.62 & 4,000 & 1,010 & 0.000 \\
Skull/Bone & 0.024219 & 6.1064 & 0.39 & 1,300 & 1,810 & 0.192 \\
Gray Matter & 0.60467 & 70.073 & 1.13 & 3,675 & 1,030 & 11.183 \\
White Matter & 0.35408 & 50.306 & 0.5 & 3,621 & 1,030 & 3.950 \\
Eyeball & 1.5064 & 69.052 & 0.59 & 3932 & 1,000 & 0.000 \\
Muscle & 0.72719 & 62.179 & 0.53 & 3,546 & 1,040 & 1.000 \\
Heart & 0.78866 & 80.671 & 0.54 & 3,720 & 1,040 & 15.000 \\
Air & 0 & 1 & 0.025 & 1010 & 1.165 & 0.000 \\
Dielectric Bolus & 0 & 75.0 & 0.6 & 4.200 & 1,000 & 0.000 \\
\hline
\end{tabular}

$\sigma$ : electrical conductivity, $\varepsilon_{r}$ : relative permittivity,

$\kappa:$ thermal conductivity, $c$ : specific heat, $\rho$ : volume density, $B$ : blood flow rate 


$$
\begin{aligned}
& \nabla^{2} E+k^{2} E=0 \\
& \rho c \frac{\partial T}{\partial t}=\operatorname{div}(\kappa \cdot \operatorname{grad} T)+W_{h}-W_{c}+M \\
& W_{h}=\frac{1}{2} \sigma|E|^{2} \\
& W_{c}=(F \rho)_{\text {tissue }} \times(\rho c)_{\text {blood }} \times\left(T-T_{b}\right) \\
& M=M_{0}(1.1)^{\Delta T}
\end{aligned}
$$

$k^{2}=\omega^{2} \varepsilon \mu, \omega$ : 角周波数, $\varepsilon$ : 誘電率, $\mu$ : 透磁率, $\rho$ : 体積, $c:$ 比熱, $\kappa$ : 熱伝導率, $\sigma:$ 電気伝導率, $F$ : 血流量,

$T_{b}:$ 血液温度, $M_{0}:$ 基礎代謝熱

\section{3. 結果と考察}

図 4 は, 誘電体ボーラスを設置していない場合の温度分 布解析結果を示している。共振周波数は $166.6 \mathrm{MHz}$ であっ た. 図 4 からわかるように, 脳内の腫瘍が， $42 \sim 43^{\circ} \mathrm{C}$ 程度 に加温されていることが確認できる。一方, 頭部側面から 首部にかけての発熱が高く, $47^{\circ} \mathrm{C}$ 程度に加温されているこ とが確認できる。

図 5 は, 誘電体ボーラスを設置した場合の温度分布解析 結果である. 共振周波数は $156.7 \mathrm{MHz}$ であった。図 5 から わかるように, 脳腫瘍が $42 \sim 43^{\circ} \mathrm{C}$ 程度に加温されているこ とが確認できる. 一方で頭蓋骨から灰白質付近にかけて最 高温度 $46^{\circ} \mathrm{C}$ 程度に加温されていることがわかる。

図 4 と図 5 とを比較すると, 首部および頭部表面の温度 が，誘電体ボーラスを設置することで， $41^{\circ} \mathrm{C} \sim 42^{\circ} \mathrm{C}$ 程度に 緩和されていることが分かる。この理由は, 誘電体ボーラ スを頭頂部付近に設置したことで，リエントラント部の電 気力線が頭頂部に集中したため, 加温位置が誘電体ボーラ スの方向に移動したためであると考えている.

臨床において, 安全なハイパーサーミアを行うには, 脳 腫瘍部が最高温度であることが望ましい，しかしながら， 今回の結果ではホットスポットの発生位置が, 脳腫瘍部で はないことがわかった。 今後は, 誘電体ボーラスの電気的 特性を変更し, 加温位置の制御の検討を行うことを考えて いる.

\section{4.まとめ}

本報告では, 空胴共振器加温方式において, 誘電体ボー ラスを用いた加温位置制御の方法を提案した。さらに，3 次元人体解剖学的モデルを用い, 血流による冷却効果を考 慮した FEM 温度分布解析手法により, 本手法の有用性を 数值的に示した。

5 . 参考文献

（1）加藤和夫ほか, 深部癌の非接触温熱治療を目的とした 空胴共振器アプリケータの設計・試作, 設計工学会, Vol.39, No.11, (2004), pp. 627-631.

（2）井関祐也，加藤和夫ほか，誘電体ボーラスによる空胴 共振器アプリケータの加温位置制御, 日本機械学会熱 工学コンファレンス講演論文, (2010), pp. 169-170.

(3) Dielectric Properties of Body Tissues, Available: http://niremf.ifac.cnr.it/tissprop/

(4) Esra Neufeld, "High Resolution Hyperthermia Treatment Planning", PhD thesis, ETH Zurich, August 2008.

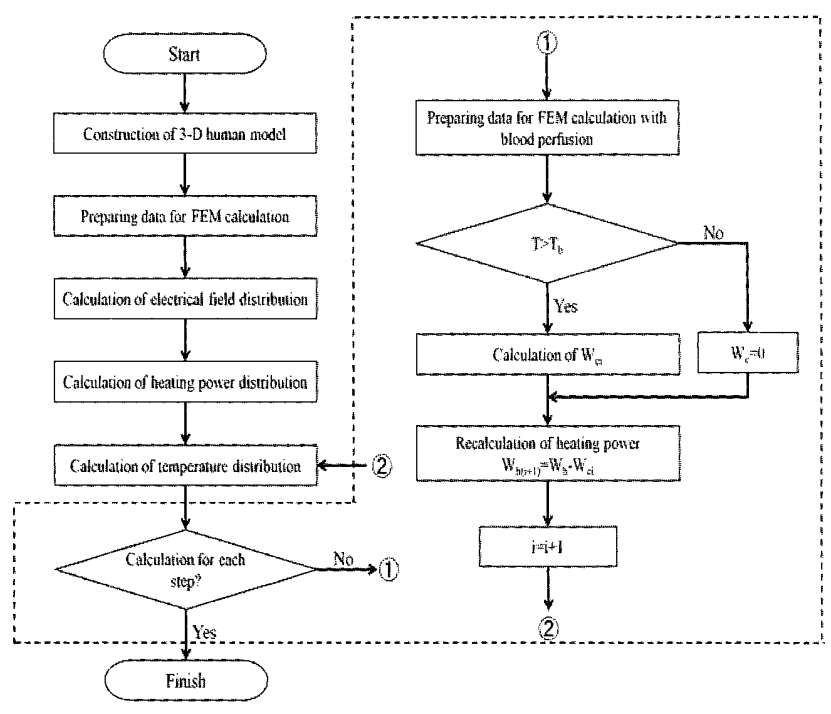

Fig. 3 Algorithm of calculating temperature

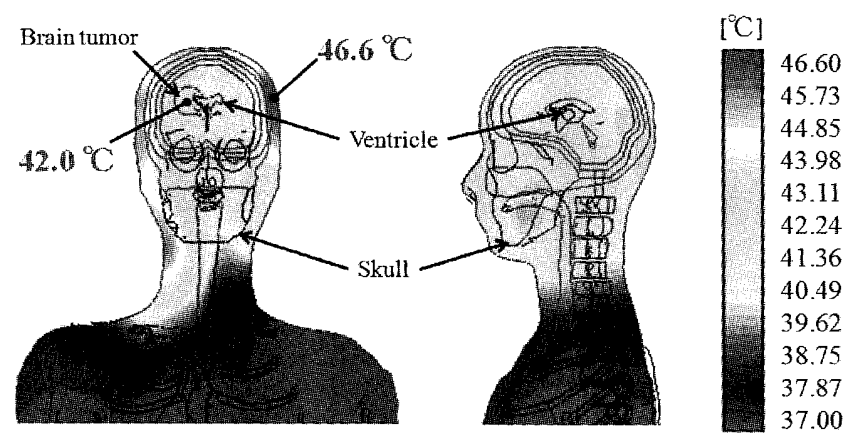

(a)

(b)

Fig. 4 Temperature distributions without bolus (Resonant frequency: $166.6 \mathrm{MHz}$ )

(a) front of view, (b) side of view.

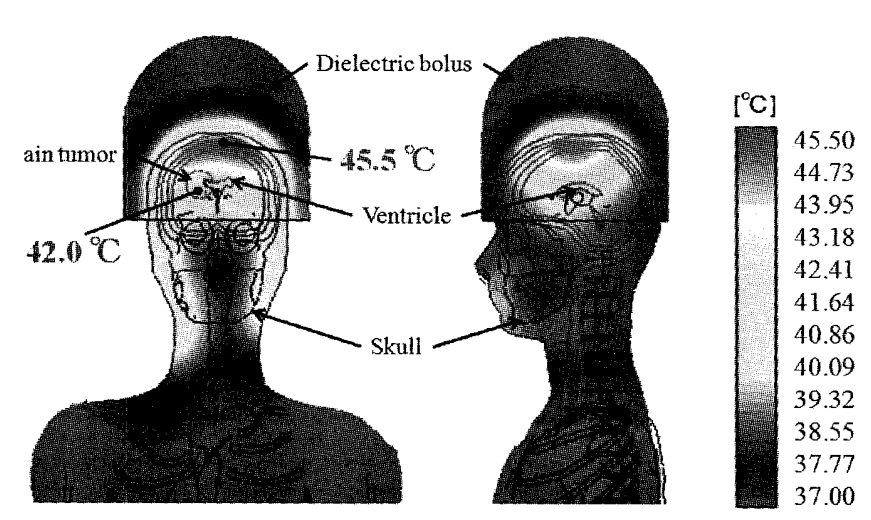

(a)

(b)

Fig. 5 Temperature distributions with bolus (Resonant frequency: $156.7 \mathrm{MHz}$ )

(a) front of view, (b) side of view. 